\title{
Some Aspects of Tehran's Ecological Footprint
}

\author{
Simin Tavallai \\ Tarbiat Moallem University, Department of Geography, No 49, Moffateh Ave, Tehran Iran \\ E-mail: tavallai@tmu.ac.ir,simintt@yahoo.com \\ Farzaneh Sasanpour \\ far20_sasanpour@yahoo.com \\ Tarbiat Moallem University, Department of Geography, No 49, Moffateh Ave, Tehran Iran
}

\begin{abstract}
Ecological footprint is a way of measuring urban and regional ecological impacts and guides communities toward sustainability. This Technique measures how much land is required to supply our living and lifestyle including food, housing, energy/fuel, transport, and consumer goods and services along with their corresponding energy requirements.

This study aims to quantify Tehran's ecological impacts through ecological foot prints technique. it suggests that Tehran's metropolitan per capita ecological footprint corresponding with energy in all of the consumption fields is close to 2.9 hectares. This means that taking into consideration the current consumption pattern, Tehran metropolitan require 22 million hectares in order to meet the relevant energy requirements.

Tehran's total per capita ecological footprint is 3.79 hectares. This is corresponded with 28482098 hectares . The most conspicuous figure is associated with goods and services sector (2.66). In fact, Tehran's citizens are utilizing nearly 2.5 of their actual share of their ecological capacities and thus abusing their hinterlands.
\end{abstract}

Keywords: Tehran, Ecological footprint, Service sector, Urban hinterland, Sustainability

\section{Introduction}

Most changes in the ecosystem are a result of human land-use practices, including agriculture and industrialization. Urbanization is unique in this regard both in terms of the intensity and the extent of its impacts upon natural ecosystems.

Rapid growth of the human population in the twentieth century along with migration into larger cities would intensify the matter.

It is projected that the global urbanization rate will reach 50 percent in 2007, and in 2030 it should reach 60 percent. In other words, the world's population could increase by 2.2 billion people in 2030, with 2.1 billion of these people living in cities. (http://www.gdrc.org/uem/footprints/what-is-ef.html).

Cities intensively act as centers of human consumption. In fact, major local changes in supply and at the same time drastic increase in consumption level, have allowed societies to overcome regional limits to sustainable consumption levels, and take a risk of depleting other places.

Cities placing further environmental burdens on city hinterlands. They have drawn in energy and matter from all over the ecosphere (Wackernagel and Ress, 1996, 237).

Population growth and changing consumption patterns have increased the demand for resources.

However, sustainable access to natural resources, particularly those related to food, has been a crucial factor in human development throughout history (Hopfenberg and Pimentel, 2001; De Vries and Goudsblom, 2002).

Total global consumption of natural resources has risen by fifty percent since 1970; while Earth's natural wealth has decreased by over thirty percent (Living Planet Report, 2000).

In 2002 the biosphere had 11.3 billion hectares of biologically productive area corresponding to roughly one-quarter of the planet's surface (Wackernagel and others,2006). 
Biocapacity represents the "endowment" of ecologically productive territory that is locally available and it indicates the local ecosystems potential capacity to provide natural resources and services (Macro Bagliani and others, 2008). This quantity can be compared with the ecological footprint, which provides an estimate of the land area necessary to sustain current levels of resource consumption for a given population.

\section{The review of literature}

The concept of the 'Ecological Footprint' (EF) was introduced in the early 1990s to more clearly express the possible ecological consequences of human consumption patterns compared to the earth's carrying capacity, (Rees, 1992; Wackernagel and Rees, 1996). The EF is defined as the amount of environmental resources required to support the consumption of a defined population (Detlef and others, 2005).

The measurement units for Footprint accounts are global hectares. They are adjusted hectares that represent the average yield of all bioproductive areas on Earth. More precisely, a global hectare is one hectare of biologically productive space with world average productivity for the given year (Wackernagel and others, 2006 ).

The global EF covered 13.7 billion ha in 1999, or 2.3 global ha per person (a global hectare is 1 ha of average biological productivity), while the global ecological carrying capacity was only 11.4 billion ha (Bindu and others, 2006).

Knowing ecological foot print of a region then it is possible to define an ecological balance for the territory: its balance is obtained by subtracting from the local population's needs for natural resources (the ecological footprint), the local availability of those resources (biocapacity). A negative balance which is most probable indicates a condition of ecological deficit .Rees argued that this would outline a situation of unsustainability in which the rate of consumption of natural resources is greater than the rate of regeneration by local ecosystems (Rees, 1996).

In 2002, humanity's Ecological Footprint exceeded the Earth's biocapacity by more than 20 percent (Wackernagel and others, 2006)

Thus it is possible to exceed global biocapacity, entering overshoot, because trees can be harvested faster than they re-grow, fisheries can be depleted more rapidly than they restock and $\mathrm{CO}_{2}$ can be emitted into the atmosphere more quickly than ecosystems can sequester it.

Obviously, the size of a footprint will vary depending on the volume and different types of natural resources consumed by a population, their consumption level which will in turn depend on lifestyle choice, income levels, and technology (http://www.gdrc.org/uem/footprints/what-is-ef.html).

If the global population were to consume resources on a level comparable to Western states, an additional two plants would be required. In fact most developed countries have a footprint of over six global hectares (Conorwalsh and others, 2006)

The ecological footprint of an average world citizen is nearly about 2.8 hectares or 6.92 acres. However, the ecological foot print of one average American is 10.3 hectares or 25.45 acres. By contrast, in India the average person uses about 1.98 acres (http://allspecies.org/neigh/nbrfootp.html).

Consumption-land-use matrix regarding ecological foot print has five major consumption categories and six major land use categories. Consumption categories include food, housing, transportation, consumer goods and services.

The land is divided into 6 categories: (1) cropland; (2) grazing; (3) forest; (4) fishing ground; (5) built-up land; (6) energy land.

In calculating the ecological footprint, conversion factors are of great relevance: they allow translating a local population consumption of goods and services into the corresponding area of land that is directly or indirectly used for their production (Macro Bagliani and others, 2008).

In order to convert to area figures, the national consumption values (in terms of tones of oil equivalent) were converted to units of energy(Conorwalsh and others, 2006). Wackernagel and Rees in fact provided different ideas on which the conversion of $\mathrm{CO}_{2}$ emissions to equivalent land area could be based, in particular (1) the forest area required for sequestering the $\mathrm{CO}_{2}$ and (2) the area needed for producing the same amount of fossil-fuel-based energy by biofuels (wackernager\& REES,1996).

Based on these prominent ecological facts associated with ecological foot print from one hand, and Tehran's present urbanization rate (1.4) and its subsequent consumption level and Tehran's area (733 square $\mathrm{km}$ ) on the other hand, determination of Tehran's ecological footprint in the area of food, housing, consumer goods and services and transportation receive considerable attention. This requires calculation of different land uses along with their corresponding energy usages. 


\section{Calculation of Tehran's Ecological Footprint}

Calculation of Tehran's Ecological Footprint requires the list of land uses along with their corresponding areas (Table 1).

This table suggests that the most dominant land use is associated with the service sector. This is followed by residential land use with 171 square $\mathrm{km}$ which comprised $25.7 \%$ of the total. Agricultural lands, horticulture, and those under dairy activities turned out to be near 60 square $\mathrm{km}$. This is followed by non-built areas which comprised close to 50 square $\mathrm{km}$.

Calculation of ecological footprint requires determination of the amount of energy consumption in each consumption field including transportation, consumer goods, agriculture, housing and services taking into consideration corresponding type of energy (Table 2).

As the table suggests service sector with energy consumption of 107552 milliards MJ is the greatest user (organization of Iran's petroleum products, 2005). Wackernagel and Rees suggest that on average 1 hectare of forest can sequester the $\mathrm{CO}_{2}$ emissions generated by the consumption of $100 \mathrm{GJ}$ of fossil fuel each year (Bicknell and others, 1998).

This would intensify the magnitude of the problem associated with the required energy land in this sector.

Table 3 shows Tehran's metropolitan per capita ecological footprint in the area of energy consumption in each sector.

As the table suggests, service sector with 1.43 hectares per capita ecological footprint is on the top of the list. Same thing would almost apply to the area of consumption goods (1.22). Tehran metropolitan's per capita ecological footprint corresponding with energy in all of the consumption fields is close to 2.9 hectares. This means that taking into consideration the current consumption pattern, Tehran metropolitan require 22 million hectares (294 times of its present area) in order to meet their needs.

As a matter of fact Cities placing further environmental burdens on city hinterlands. They have drawn in energy and matter from all over the ecosphere (Wackernagel and Ress, 1996a: 237).

Ecologically speaking, Tehran puts its steps on vast areas including Gilan, Mazandaran, Semnen, Isfahan and Chaharmahal in order to meet its needs (map 1).

Table 4 shows the amount of Tehran's deficit energy land in different sectors.

Wackernagel and Rees in fact provided different ideas on which the conversion of $\mathrm{CO}_{2}$ emissions to equivalent land area could be based, in particular (1) the forest area required for sequestering the $\mathrm{CO}_{2}$ and (2) the area needed for producing the same amount of fossil-fuel-based energy by biofuels (Wackernagel and Rees,1996).

This table suggests that Tehran's total ecological lands pertaining to service sector is close to 11 million hectares. This is followed by Tehran's total ecological lands in the area of consumer goods ( 9 millions hectares)

Thus the deficit energy land associated with service sector is the highest (146 times of Tehran's present area). In general, Tehran needs 293 of its present area in order to meet all of the required energy in the area of transportation, consumer goods, agriculture, residential, and services.

\subsection{Tehran's ecological footprint in the area of food}

The most dominant food items of Tehran's citizens in the area of plant is wheat, grains, vegetable, fruits, oil and shortening, and sugar with per capita consumption of $1.50 \mathrm{Kg}$. Per capita animal consumption of animal products is $1.78 \mathrm{Kg}$.

However, energy consumption relating to agricultural section was $230906 \mathrm{MJ}$.That is per capita energy consumption in this area turned out to be $30.787 \mathrm{MJ}$.

Matrix associated with Tehran's metropolitan ecological foot print in food sector consumption which contains energy land(Note 1), crop lands, grazing land, fishing ground, built-up lands in area unit per person shows interesting results (table 5).

Tehran's per capita ecological footprint pertaining to food in general is 0.91 hectare. It means that the total land needed to meet Tehran's needs taking into consideration their present consumption and production patterns are 6790791 hectares. That is Tehran needs 93 times of its present area in order to meet its needs.

\subsection{Per capita ecological footprint in the area of consumer goods and services}

According to this study the total amount of energy consumption in the area of consumer goods and services is 912 million GJ. Its corresponding per capita energy consumption is 122 and 143 millions GJ respectively (Fao Statistcs,2005). Taking into consideration that each $100 \mathrm{GJ}$ energy associates with one hectare of ecological lands, per capita ecological footprint are amounted to be 1.22 and 1.43 hectares respectively. That means that meeting Tehran's needs in this area require 125 times of its present area which is drained from Tehran's hinterlands. Tehran's 
consumption level in the area of wood consumption is associated with 0.1 hectare of forest per person. In effect, total ecological footprint in the area of consumer goods and services is around 2.66 hectares which is the greatest comparing with the other areas and fields.

That is if Tehran's citizen is to keep their present consumption and production levels, Tehran needs 273 times of its present area.

\subsection{Tehran's ecological footprint in the area of housing}

Residential sector is occupying 171 millions square meters. Per capita energy consumption associated with this sector is over 2 million MJ. However, as already mentioned each hectare of land is associated with $100 \mathrm{GJ}$ of energy. Per capita ecological footprint pertaining to housing sector is 0.22 hectare. That is, Tehran needs 1696042 hectares of land in order to meet its needs in this field which is 23 times of its present area.

\subsection{Ecological foot print in the area of transportation}

The amount of energy associated with transportation is over $1212682486 \mathrm{MJ}$. It has been argued that the types of consumption that most contribute to the energy component of the ecological footprint are transportation (1.23 global hectare, gha, per capita)( Macro Bagliani and others, 2008). Tehran's per capita energy consumption in this area is over 16 millions MJ. Knowing the fact that each ha is associated with $100 \mathrm{GJ}$, so that its per capita ecological footprint would be 0.0016 hectare. Thus, Tehran's present population is utilizing 12.127 hectares in order to meet its energy requirements in the area of transportation (organization of atomic products, National Gas Company 2005).

Taking into consideration Tehran's approximate coverage under transportation (160 000000 sequare meters), and its population, per capita ecological footprint in the area of transportation turned out to be 0.0038 hectare. In other word, Tehran needs over 28 million hectares in order to meet its needs in the area of transportation.

\subsection{Total Tehran's Ecological Footprint}

Ecological footprint shows the relationship between different sectors including food stuffs, housing, transportation, consumer goods and services; and the amount of needed lands associated with each sector. Interestingly enough, the land needed for housing not only include the lot itself, but also all associated lands pertaining to provision of utilities as well as lands linked with construction materials. Table 5 shows associated needed lands in different sectors pertaining to Tehran's ecological footprint.

Columns 1,2,3,4,5, and 6 indicate the energy lands , the agricultural lands, grazing land for production of dairy products, and meat, built areas and infertile lands, and the needed fishing ground to support the population's sea foods associated with each corresponding sector.

This table suggests that Tehran's total per capita ecological footprint is 3.79 hectares. This is corresponded with 28482 098 out of this the most prominent figure is associated with consumer goods and service sector (2.66). Deficiency in terms of provision of goods and services is greatest (272 times of its present area). This is followed by deficiency in the area of food stuff (92 times of its present area).

\section{Conclusion}

The concept of an "ecological footprint" the amount of land required to produce the resources needed by one person, attempts to quantify humanity's impact on nature. This has received considerable attention as a useful indicator in the context of sustainable development. Tehran's per capita ecological footprint is amounted to be 3.79 hectares. However, Tehran's per capita ecological footprint is not identical in each field. Tehran's per capita ecological footprint in the area of animal and plant food, goods and services, housing, and transportation is $0.91,2.66,0.22$ and 0.0038 hectare respectively. Taking into account the country's ecological footprint, 2.42, Each Tehran's citizen is putting her steps on 1.37 hectares of its hinterlands. Comparing with world per capita ecological footprint (1.5), Tehran's ecological footprint is 2.29 larger. This means that each Tehran's citizen is utilizing nearly 2.5 times of its actual share. This in turn, has led to instability of Tehran as well as its hinterlands. In fact, with humanity's current demand on nature overshoot is no longer merely a local but, rather, a global phenomenon. Long run economic welfare depends upon meeting the criteria of strong sustainability. This resource accounting tool can assist local governments in managing their ecological assets, and support their sustainability efforts.

\section{References}

Bagliani,a,b, M., , Gallic, A., Niccoluccic, V., \& Marchettinic, N. (2006). ecological footprint analysis applied to a sub-national area: the case of the province of Siena (Italy), journal of environmental management: ecological footprint analysis page 1 of 28 .

Ball, J. R., Bicknell, B. K., Bigsby, R. H., \&Cullen, R. (Nov 1998). New Methodology for the Ecological Footprint with an application to the New Zealand Economy, Ecological Economics, volume 27,Issue 2, pages 149-160

Boom Sazaun consultant Engineer, 2006. 
De Vries, H.J.M., Goudsblom J. (2002). Mappae Mundi - Humans and their habitats in a socio-ecological perspective: Myths, maps, methods and models. Amsterdam University Press

Du, B., Zhang, K., Song G., \& Wen, Z. (2006). Methodology for an Urban Ecological Footprint to Evaluate Sustainable Development in China, international journal of sustainable development \& world ecology 13, 245-254.

Hopfenberg, R., Pimentel, D. (2001). human population numbers as a function of food supply, environment, development and sustainability 3, 1-15.

Kraft, M., Is Your Neighborhood Sustainable? http://www.allspecies.org/neigh/nbrfootp.htm

Organization of atomic products, (2005). National Gas company.

Rees, W. E. (1996). Revisiting carrying capacity: area-based indicators of sustainability, population and environment Volume 17, 3, pp. 195-215.

Ress, W. E. (1992). ecoligical footprint and appropriated carrying capacity: what urban economics leave out, environment and urbanization 4 (2), 120-130, 1992.

Tehran's distribution organization of petroleum products, 2005

Urban Environmental Governance, for sustainable development in Asia and the pacific: A regional overview (2005), United Nations Publication, http://www.gdrc.org/uem/footprints/wat-is-ef/html

Vuuren, D, P.van, Bouwman, L, F. (2005). Exploring past and future changes in the ecological footprint for world regions,Ecological Economics 52,43-62

Wackernagel, M, Kitzes, J, Moran, D, Goldfinger S, \& Thomas, M. (2006). The ecological footprint of cities and regions: comparing resource availability with resource demand, Environment and Urbanization, Volume 18, 103.

Wackernagel, M., \& Rees, W. (1996). urban ecological footprints: why cities cannot be sustainable-and why they are a key to sustainability, environmental impact assessment review, 16(4-6), 223-248.

Wackernagle, M., Ress, W. E. (1995). our ecological footprint: reducing human impact on the earth, Gabriola Island, British Columbia, Canada, New Society Publishers.

Walsh, C, McLoone A, O'Regan, B, Moles R, \& Curry Robin. (2006). The application of the ecological footprint in two Irish urban areas: Limerick and Belfast, Irish geography, volume 39 (1), 1-21, 2006.

WWF, UNEP-WCMC. (2000). living planet report, world wildlife, found editor.

Note 1.

The land area corresponding to fossil fuel consumption can represented as the productive land necessary to produce the equivalent amount of energy 
Table 1. Tehran's land uses

\begin{tabular}{|c|c|c|c|c|}
\hline & Type of land uses & Area & $\%$ & Per-capita \\
\hline 1 & Residential & 171215356 & 25.7 & 23.1 \\
\hline 2 & Commercial & 14972236 & 2.3 & 0.2 \\
\hline 3 & Education & 6956236 & 1 & 0.9 \\
\hline 4 & Higher education & 9824875 & 1.5 & 1.3 \\
\hline 5 & Religious & 2327530 & 0.3 & 0.3 \\
\hline 6 & Cultural & 2568414 & 0.4 & 0.3 \\
\hline 7 & Tourism & 647899 & 0.1 & 0.1 \\
\hline 8 & Medical & 3824606 & 0.6 & 0.5 \\
\hline 9 & Recreational & 1646122 & 0.2 & 0.2 \\
\hline 10 & Sport & 8400939 & 1.3 & 1.1 \\
\hline 11 & Administrative & 9790210 & 1.5 & 1.3 \\
\hline 12 & Green space & 61492474 & 9.2 & 8.3 \\
\hline 13 & Military & 56368359 & 8.5 & 7.6 \\
\hline 14 & Industrial & 38175996 & 5.7 & 5.1 \\
\hline 15 & Infrastructure & 5786145 & 0.9 & 0.8 \\
\hline 16 & Transportation & 31912092 & 4.8 & 4.3 \\
\hline 17 & Non- built & 47726813 & 7.2 & 6.4 \\
\hline 18 & Reads \& pavement & 132224315 & 19.9 & 17.8 \\
\hline 19 & Social \& public services & 972590 & 0.1 & 0.1 \\
\hline 20 & Ravines & 5737799 & 0.9 & 0.8 \\
\hline 21 & Agriculture & 19104118 & 2.9 & 2.6 \\
\hline 22 & Horticulture & 19510118 & 2.9 & 0.2 \\
\hline 23 & Dairy & 19510324 & 0.2 & 1.7 \\
\hline 24 & Others & 1212566 & 1.9 & 4.7 \\
\hline \multicolumn{2}{|c|}{ Total } & 665297395 & 100 & 89.7 \\
\hline
\end{tabular}

Source: Boom Sazaun consultant Engineer, 2006, p.116

Table 2. energy consumption in MJ

\begin{tabular}{|c|c|c|c|c|c|c|c|}
\hline & Total & Electricity & Natural Cas & Fuel oil & Casoil & kerosene & Casoline \\
\hline Transportation & 121268248617 & 4599853 & 5240998000 & 0 & 6236764 & 0 & $\begin{array}{lll}116 & 016 & 414 \\
000 & & \end{array}$ \\
\hline $\begin{array}{l}\text { Consumer } \\
\text { goods }\end{array}$ & 91161895707416 & 1336079 & $\begin{array}{llll}1 & 379 & 210 & 000 \\
000 & & & \end{array}$ & $\begin{array}{llll}89 & 683 & 576 & 560 \\
000 & & & \end{array}$ & 1001673 & 99106809664 & 0 \\
\hline Agriculture & 230905634538 & 1113239 & 0 & 221203829056 & 556851 & 9700135392 & 0 \\
\hline Housing & 16037920627712 & 29148509 & 292313708000 & 0 & 2184547 & 15745575586656 & 0 \\
\hline Services & 107551990218282 & 16560000 & 47287200000 & 1230170107008 & 283695 & 1954831153960 & 1520905000 \\
\hline Total & 21510398043656 & 52757680 & $\begin{array}{llll}1 & 724 & 051 & 906 \\
000 & & & \end{array}$ & $\begin{array}{llll}91 & 134 & 950 & 496 \\
064 & & & \end{array}$ & 10263530 & 17809213685672 & 117537319000 \\
\hline
\end{tabular}

Source: Tehran's distribution organization of petroleum products, 2005 
Table 3. Per capita Tehran's ecological footprint pertains to energy consumption in hectare

\begin{tabular}{|l|l|}
\hline Sector & Per capita ecological footprint \\
\hline Transportation & 0.00 \\
\hline Consumer goods & 1.22 \\
\hline Agriculture & 0.00 \\
\hline Housing & 0.21 \\
\hline Services & 1.43 \\
\hline Total & 2.87 \\
\hline
\end{tabular}

Source: Authors computation

Table 4. Tehran's deficit energy land

\begin{tabular}{|l|l|l|l|}
\hline Sector & $\begin{array}{l}\text { Per capita ecological } \\
\text { footprint }\end{array}$ & $\begin{array}{l}\text { Tehran's ecological } \\
\text { lands (ha) }\end{array}$ & $\begin{array}{l}\text { Tehran's deficit } \\
\text { energy land (ha) }\end{array}$ \\
\hline Transportation & 0.001616910 & 12126.82486 & 0.165440994 \\
\hline Consumer goods & 1.215494943 & 9116189.571 & 124.368207 \\
\hline Agriculture & 0.003078742 & 23090.56345 & 0.315014508 \\
\hline Housing & 0.213838942 & 1603792.063 & 21.87983715 \\
\hline Services & 1.434026536 & 10755199.02 & 146.7284996 \\
\hline Total & 2.868053072 & 21510398.04 & 293.4569992 \\
\hline
\end{tabular}

Source: Authors computation

Table 5. food, land uses matrix corresponding with ecological footprint

\begin{tabular}{|l|l|l|l|l|l|l|l|l|l|}
\hline \multicolumn{1}{|c|}{$\begin{array}{l}\text { Land use } \\
\text { consumption }\end{array}$} & Energy land & Agriculture & $\begin{array}{l}\text { Grazing } \\
\text { land }\end{array}$ & Forest & Built land & $\begin{array}{l}\text { Fishing } \\
\text { ground }\end{array}$ & $\begin{array}{l}\text { Total E.F } \\
\text { land (ha) }\end{array}$ & $\begin{array}{l}\text { Deficit land } \\
\text { (ha) }\end{array}$ \\
\hline Food stuff & 0.003078742 & 6.40 & 0.1 & 0 & 0.00172 & 0.8 & 0.90543874 & 6790790.565 & 92.64380034 \\
\hline $\begin{array}{l}\text { Plant food } \\
\text { stuff }\end{array}$ & 0 & 0.00048 & 0 & 0 & 0.001501429 & 0 & 0.00198143 & 14860.7175 & 0.202738302 \\
\hline $\begin{array}{l}\text { Animal food } \\
\text { stuff }\end{array}$ & 0 & 0.00016 & 0 & 0 & 0.000217792 & 0 & 0.00037779 & 2833.44 & 0.038655389 \\
\hline Housing & 0.213838942 & 0 & 0 & $0 / 01$ & 0.0023 & 0 & 0.226138942 & 1696042.065 & 23.13836378 \\
\hline $\begin{array}{l}\text { Under } \\
\text { construction }\end{array}$ & 0 & 0 & 0 & 0 & 0.000009 & 0 & 0.000009 & 67.5 & 0.000920873 \\
\hline $\begin{array}{l}\text { Transportatio } \\
\mathrm{n}\end{array}$ & 0.00161691 & 0 & 0 & 0 & 2.20 & 0 & 0.00381691 & 28626.825 & 0.390543315 \\
\hline $\begin{array}{l}\text { Surface } \\
\text { transportation }\end{array}$ & 0 & 0 & 0 & 0 & 0.001388716 & 0 & 0.001388716 & 10415.37 & 0.14209236 \\
\hline Rail road & 0 & 0 & 0 & 0 & 0 & 0 & 0.00 & 0 & 0 \\
\hline Aviation & 0 & 0 & 0 & 0 & 0.000132053 & 0 & 0.000132053 & 990.3975 & 0.013511562 \\
\hline Infrastructure & 0 & 0 & 0 & 0 & 0.0 & 0 & 0.00 & 0 & 0 \\
\hline $\begin{array}{l}\text { Goods } \\
\text { services }\end{array}$ & 2.649518479 & 0 & 0 & 0.01 & 0.0027 & 0 & 2.662218479 & 1966638.59 & 272.3961609 \\
\hline Total & 2.868053073 & 6.40 & 0.1 & 0.02 & 8.92 & 0.8 & 3.797613073 & 28482098.05 & 388.5688683 \\
\hline
\end{tabular}




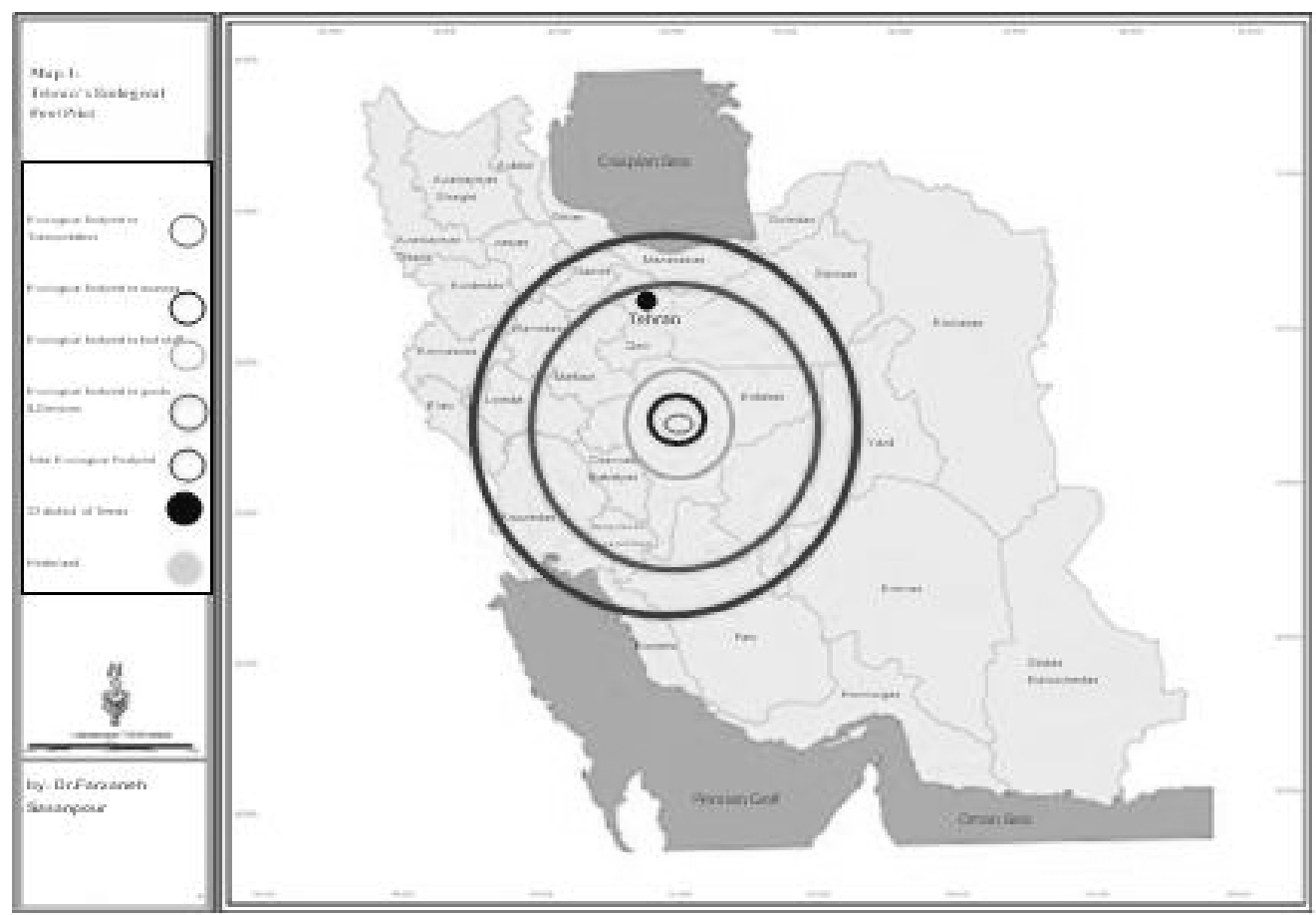

Map 1. Ecological footprint of Tehran's metropolitan 